\title{
Corporate Ownership and the Technical and Scale Efficiency of Pharmaceutical Firms in India - Empirical Evidence
}

Kuldip Kaur, Sunil Kumar*

\section{Abstract:}

In the existing literature, the theoretical models suggest that foreign-owned firms perform better than domestic firms and that private sector firms perform better than public sector firms. The present study is a modest attempt in this regard to empirically test and compare the differences in the technical and scale efficiencies of 36 public limited companies, private sector firms and foreign firms belonging to the pharmaceutical industry of India using the DEA model. The analysis shows that overall technical efficiency was different in the case of private domestic and public sector firms in the year 1990, i.e., the pre-reform period. The difference was also significant in the case of private foreign and public sector firms, though it was not significant in the case of private domestic and private foreign firms in the pre-reform period. However, in the subsequent post-reform years, there were no significant differences.

Keywords: Corporate Ownership, Technical Efficiency, Scale Efficiency

JEL: G34, D61, G21

DOI: 10.2478/v10033-010-0019-y

\section{Introduction}

Productivity and efficiency growth are the key factors for the development of any industry. An efficient industry has significant spillover effects on the economy. In addition, economic development often is viewed as a process through which inefficient firms converge with efficient firms. A necessary condition for this convergence is that inefficient firms get the benefits or spillovers from efficient firms. It has been about two decades since India initiated the LPG policies with the core objective of improving the efficiency of the industrial sector of India. The channel behind was to make imported inputs cheaper and more accessible to the firms and exploring the advantages in the domestic and international markets. In addition, these policies have been designed to attract more and more foreign firms (FDI) into the economy. The expectation was that, since foreign firms are supposed to be more efficient than domestic firms, more spillovers are likely to emerge for these firms. This point is made clearer by Helpman et al. (2004), when they concluded that in advanced economies the most efficient firm is that which engages in FDI. One can also assume that if the domestic firms are able to follow the productivity level of a foreign firm, they can reach the world standard.

In the existing literature, the theoretical models suggest that foreign owned firms perform better than domestically owned firms. This is mainly because of the superiority of the firm's specific assets, particularly in the case of intangible assets related to the production process, marketing networks and management capability, which is a necessary condition for a firm to become a multinational corporation (MNC). Also, foreign firms are expected to be more efficient compared to domestic firms because only through greater efficiency
* Kuldip Kaur
Punjab School of Economics
Guru Nanak Dev University, India
e-mail: kuldeepgarcha@yahoo.co.in

\section{Sunil Kumar}
Punjab School of Economics
Guru Nanak Dev University, India
e-mail: sunil12eco@yahoo.com 
can they manage their production in another country. There have been a number of empirical studies on the effects of ownership of firms on productivity and efficiency. However, these empirical findings are not consistent and very often they are contrary to each other. One group of studies observed that foreign firms are more productive and efficient than domestic firms. These results have been reached for different countries and also from cross country comparisons. The studies of Hill (1988), Blomstrom (1990), Sjoholm (1998), Ramstetler (1999), Okamoto and Sjoholm (2000), Hallward Driemcier, larossia and Sokodoff (2002) and Bernard and Bradfrd (2004) Camson et al (2002), Collins and Harris (1999), Grima et al (1999) have found that foreign firms use better technology in production than domestic firms.

Another important point is that in the case of developing countries like India, foreign firms are assumed to be more efficient than domestic firms because they have better access to modern and advanced technology. This is one of the reasons why governments attract more foreign firms with the expectation that flow will bring advanced technology, and thus generate productivity gain for the domestic firms. In addition, there may be a number of other reasons like foreign firms generating more output from the inputs, inability to charge high prices due to lower product quality or inferior marketing, fewer intangible assets, higher cost of capital, more inefficient vertical integrations, etc.

However, the studies of Artken and Harrison (1999), Konings and Murphy (2001), Oguchi (2002) and Barbose and Lousi (2005) could not find any significant difference in the performance of both types of firms. In the case of India, very few studies are available which try to find out the efficiency of the different sectors in India (see, for example, Mitra (1999), Agarwal (2001), Driffield and Kambhampati (2003), Kambhampati (2003), Golder, Ranganathan and Banga (2004), Kathuria (2002), etc.) Pandit and Siddharthan $(1998,2003)$ have shown that MNC's have many advantages over domestic firms (and therefore are better performers). Also Chhibber and Majumdar (1997) have failed to find any difference between both types of firms.

The explanation for this conflicting evidence is that the productivity and efficiency gains from globalization of firms depend not only on ownership but on a range of factors, for example the absorptive capacity (Borzenstein et al, 1998; Alfardo et al, 2003; Edison et al, 2002; Durham, 2004) of the country. The initial conditions that capture the absorptive capacity of host countries include the initial level of development (Blomstorm et al, 1992), existing human capital development (Borenztein et al, 1998) trade policy (Balasubramanyam et al, 1996) financial development (Durham, 2003; Alfaro et al, 2003), legal based variables (Durham 2004; Edison et al, 2002) and general government policy (Edison et al, 2002).

To contribute to this ongoing debate the present paper seeks to compare the efficiency of domestic firms and foreign firms. Domestic firms are sub-divided into two segments - Public Ltd. Companies and private sector firms. The paper is structured to comprise four sections in all including the present one. Section II discusses the data base and methodology used in the study. Section III presents the results of the analytical findings and section IV concludes the paper and draws some policy implications on the basis of empirical findings.

\section{Data Base and Methodology}

The importance of the efficient use of resources has long been recognized, but mainstream neoclassical economics assumes that the producer in an economy always produces efficiently. In reality, however, the producers are not always efficient. Two identical firms never produce the same output and cost and profits are also not the same. This difference in output cost and profits, etc. can be explained in terms of technical and allocative inefficiency. Further, it is significant to find out whether the observed inefficiency in different firms is due to managerial underperformance or due to inappropriate scale size. The present study is an attempt in this direction where the measurement of the extent of technical, pure technical and scale efficiencies of individual firms belonging to the pharmaceutical industry of India has been attempted using Data Envelopment Analysis (DEA).

Before proceeding further, it is necessary to elaborate the concepts of technical, pure technical and scale efficiencies. Technical efficiency relates to the productivity of inputs (Sathye, 2001). The technical efficiency of a firm is a comparative measure of how well it actually processes inputs to achieve its outputs, as compared to its maximum potential for doing so as represented by its production possibility frontier (Barros and Mascarenhas, 2005). A measure of technical efficiency under the assumption of constant returns to scale (CRS) is known as overall technical efficiency (OTE). The OTE measure helps to determine efficiency due to the input/output configuration as well as the size of operations. In DEA, the OTE measure has been 
decomposed into two mutually exclusive and nonadditive components; pure technical efficiency (PTE) and scale efficiency (SE). This decomposition allows insight into the source of inefficiencies. The PTE measure is obtained by estimating the efficient frontier under the assumption of variable returns to scale. It is a measure of technical efficiency without scale efficiency and purely reflects managerial performance in organizing the inputs into the production process. Thus, the PTE measure has been used as an index to capture managerial performance. The ratio of OTE to PTE provides the SE measure. The measure of SE demonstrates the ability of the management to choose the optimum size of resources, i.e. to decide on the firm's size or in other words, to choose the scale of production that will attain the expected production level. Inappropriate size of a firm (too large or too small) may sometimes be a cause of technical inefficiency.

Data envelopment analysis (DEA) introduced by Charnes et al (1978) based on Farrell's work (Farrell, 1957), is a non-parametric technique for measuring the relative efficiency of a set of similar units, usually referred to as decision making units (DMU's). DEA is capable of handling multiple inputs and outputs without requiring any judgment on their importance. Earlier, the most widely applied measure to evaluate the performance of firms had been financial ratio measures. The fundamental limitation of the traditional univariate ratio analysis is that the choice of a single ratio does not provide enough information about the various dimensions of the performance of a firm. In fact, the firm's performance represents the complexity of multi-dimensional outputs and inputs. Hence it requires more than a single ratio or even selected ratios to characterize it. Another limitation of the financial ratio analysis is the choice of a benchmark against which to compare univariate or multivariate scores from ratio analysis. So the appropriate measure is DEA. This method is able to assess multiple variables simultaneously. Therefore, one can consolidate multiple measures of financial performance such as; sales, profit margin, total assets etc. in a single summary of performance measures.

DEA is an alternative as well as a complement to traditional approaches. Some methods fail to estimate the relative efficiency of individual decision making units (DMU's) as they only identify the central tendencies. DEA is a performance assessment tool useful for calculating patterns of dynamic efficiencies. Using only observed output and input data for observations, the DEA algorithm calculates an ex-post measure of how efficient each observation was in converting inputs to outputs accomplished by the construction of an empirically based production frontier and by evaluating each observation against all the others included in the data set.

Several different mathematical programming models have been proposed in the literature (see Charnes et al., 1994; Cooper et al., 2007, for details). Essentially, each of these models seeks to establish which of $n$ DMUs determine the best practice or efficient frontier. The geometry of this frontier is prescribed by the specific DEA model employed. In the present study, we utilized the CCR model, named after Charnes, Cooper, and Rhodes (1978) and the BCC model, named after Banker, Charnes and Cooper (1984) to obtain efficiency measures under CRS and VRS assumptions, respectively.

Formal notations of used input-oriented' DEA models for measuring TE scores for DMU o, under different scale assumptions are as follows.

$$
\text { [1] (i) } \min _{\theta_{o}, \lambda_{1}, \lambda_{2}, \ldots, \lambda_{n}, S_{i}^{-}, S_{r}^{+}} T E_{o}=\theta_{o}-\varepsilon\left(\sum_{i=1}^{m} S_{i}^{-}+\sum_{r=1}^{S} S_{r}^{+}\right)
$$

Subject to

$$
\begin{aligned}
& \text { ii) } \sum_{j=1}^{n} \lambda_{j} x_{i j}+s_{i}^{-}=\theta_{o} x_{i o} \\
& \text { iii) } \sum_{j=1}^{n} \lambda_{j} y_{r j}-s_{r}^{+}=y_{r o} \\
& \text { iv) } s_{i}^{-}, s_{r}^{+} \geq 0 \quad(i=1, \ldots, m ; r=1, \ldots, s) \\
& \text { v) } \lambda_{j} \geq 0 \text {, if constant returns-to-scale } \\
& \text { vi) } \sum_{j=1}^{n} \lambda_{j}=1 \text {, if variable returns-to-scale }
\end{aligned}
$$

where $\quad x_{i o}=$ amount of input $i$ used by DMU $o$, $y_{r o}=$ amount of output $r$ produced by DMU $o$,

$m$ = the number of outputs,

$s=$ the number of inputs,

$n=$ the number of DMUs, and

$\varepsilon=$ a small positive number. 
The solution to problem [1] is interpreted as the largest contraction of DMU o's input that can be carried out, given that DMU $o$ will stay within the reference technology. The restrictions ii) and iii) form the convex reference technology. The restriction $i v)$ restricts the input slack $\left(s_{i}^{-}\right)$and output slack $\left(s_{r}^{+}\right)$variables to non-negative values. The restriction $v$ ) limits the intensity variables to non-negative values. The model involving $i)-v$ ) is known as the envelopment form of the CCR model and provides Farrell's input-oriented TE measure under the assumption of constant returns-to-scale. The measure of efficiency provided by the CCR model is known as overall technical efficiency (OTE) and denoted as $\theta_{o}^{C C R}$.The last restriction imposes variable returns-to-scale assumption on the reference technology. The model involving i) - iv) and vi) is known as the BCC model and provides Farrell's inputoriented TE measure under the assumption of variable returns- to-scale. The measure of efficiency provided by the BCC model is known as pure technical efficiency (PTE) and denoted as $\theta_{o}^{B C C}$. The ratio $\left(\theta_{o}^{C C R} / \theta_{o}^{B C C}\right)$ provides a measure of scale efficiency (SE). Note that all aforementioned efficiency measures are bounded between one and zero.

As already stated, in the present study the decision making units (DMU's) are private sector, public sector or foreign owned (MNC's) firms, since the study aims at evaluating the efficiency of the different sets of firms under different management. In total 36 firms (12 from each of the abovementioned categories) belonging to the pharmaceutical industry of India have been chosen. These firms are those which survived throughout the period studied (i.e. 1989-90 to 2003-04) and remained listed on the Bombay Stock Exchange, Bombay. The required data for these sample firms have been culled for three years, i.e. 1989-90 (pre-reform period), 1999-2000 and 2003-04 (both indicating post-reform years), for the purpose of comparing the efficiency of the sample firms during the pre-reform and post-reform periods. The main source of data is the Prowess Database, 2005 version, of the Centre for Monitoring the Indian Economy (CMIE). It contains information on about 10,000 companies. The coverage includes public, private, co-operative and jointsector companies. Approximately, the coverage of this database is 70 percent of the economic activities of the country. The information available includes data from companies' profit and loss accounts, balance sheets and funds from accounts.
Three input measures (raw material cost, wages and salaries and gross fixed assets) and one output measure (net sales) have been used to compute the efficiency scores. To test whether the difference between the efficiency score of the sample firms on the basis of the ownership pattern is significant or not, a Mann-Whitney test was applied.

\section{Empirical Results}

In this section, the input-oriented efficiency scores obtained from the CCR and BCC models have been discussed. It is significant to ask here that, given that input-oriented efficiency measures answer the question, how much can input quantities be proportionally reduced without altering the output production quantities? Table 1 presents the overall technical efficiency, pure technical efficiency and scale efficiency scores of three groups of firms in the year 1990, representing a pre-reform year. Each group represents a set of twelve firms belonging to the pharmaceutical industry of India. These groups have been separated on the basis of the ownership pattern of these firms. The first group represents firms belonging to the private sector under domestic ownership. The second group represents private firms under foreign ownership. The third group belongs to firms from the public sector.

The results indicate that the OTE (in percentage terms) of private domestic firms is characterized by asymmetry, as it ranges between 38.3 percent and 100 percent. The average efficiency scores of these private firms turned out to be 0.786 . This suggests that an average private domestic firm, if producing its output on the efficient frontier instead of its current (virtual) location, would need only 78.6 percent of the inputs currently being used. The connotation of this finding is that the OTIE of private domestic firms in the Indian pharmaceutical industry is 21.4 percent. This suggests that, by adopting best practice technology, these firms can reduce their inputs of raw material, wages and salaries and gross fixed assets by at least 21.4 percent and still produce the same level of output. The potential reduction in inputs from adopting best practices varies from firm to firm. Alternatively, these firms have the scope of producing 1.27 times (i.e. 1/0.786) as much output from the same level of inputs.

Since a firm with an OTE score equal to 1 is considered to be the most efficient among the firms included in the analysis, and a firm with a score of less than one is deemed to be relatively inefficient, it can be observed 


\begin{tabular}{|c|c|c|c|c|c|c|c|}
\hline \multicolumn{8}{|c|}{ Panel A: Private Domestic Firms } \\
\hline No. & Name of the firm & $\begin{array}{c}\text { OTE } \\
\text { Score }\end{array}$ & $\begin{array}{l}\text { OTIE } \\
\text { (\%) }\end{array}$ & $\begin{array}{c}\text { PTE } \\
\text { Score }\end{array}$ & $\begin{array}{l}\text { PTIE } \\
(\%)\end{array}$ & $\begin{array}{c}\text { SE } \\
\text { Score }\end{array}$ & $\begin{array}{l}\text { SIE } \\
(\%)\end{array}$ \\
\hline 1. & Ambalal Sarabhai Enterprises Ltd. & 0.182 & 18.8 & 0.815 & 18.5 & 0.996 & 0.4 \\
\hline 2. & Amrutanjan Ltd. & 0.713 & 28.7 & 0.721 & 27.9 & 0.989 & 1.1 \\
\hline 3. & Cipla Ltd. & 0.653 & 34.7 & 0.753 & 24.7 & 0.867 & 13.3 \\
\hline 4. & Deepak Fertilizer and Petrochemicals Corpn. Ltd. & 0.383 & 61.7 & 0.387 & 61.3 & 0.99 & 1.0 \\
\hline 5. & Excel Industries Ltd. & 0.606 & 39.4 & 0.744 & 25.6 & 0.815 & 18.5 \\
\hline 6. & Kopran Ltd. & 1.0 & 0.0 & 1 & 0.00 & 1 & 0.00 \\
\hline 7. & Nagarjuna Fertilizers and Chemicals Ltd. & 1.00 & 0.00 & 1 & 0.00 & 1 & 0.00 \\
\hline 8. & Ranbaxy Laboratories Ltd. & 0.743 & 25.7 & 1 & 0.00 & 0.743 & 25.7 \\
\hline 9. & Southern Petrochemicals Inds. Corpn. Ltd. & 1.00 & 0.00 & 1 & 0.00 & 1 & 0.00 \\
\hline 10. & Sudarshan Chemicals Industries Ltd. & 0.557 & 44.3 & 0.765 & 23.5 & 0.728 & 27.2 \\
\hline 11. & Addisons Paints and Chemicals Ltd. & 0.96 & 4.00 & 1 & 0.00 & 0.960 & 4.00 \\
\hline 12. & Bihar Caustic and Chemical Ltd. & 1.00 & 0.00 & 1 & 0.00 & 1 & 0.00 \\
\hline \multicolumn{8}{|c|}{ Panel B: Private Foreign Firms } \\
\hline 1. & Abbott India Ltd. & 0.859 & 14.1 & 0.863 & 13.7 & 0.995 & 0.5 \\
\hline 2. & Albright and Wilson Chemicals India Ltd. & 0.642 & 35.8 & 0.732 & 26.8 & 0.877 & 12.3 \\
\hline 3. & Astrazencea Pharma India Ltd. & 0.809 & 19.1 & 0.826 & 17.4 & 0.979 & 2.1 \\
\hline 4. & Colour-Chem Ltd. & 0.535 & 46.5 & 0.620 & 38.0 & 0.863 & 13.7 \\
\hline 5. & Fulford (India) Ltd. & 1 & 0.00 & 1 & 0.00 & 1 & 0.00 \\
\hline 6. & Merck Ltd. & 0.543 & 45.7 & 0.590 & 41.0 & 0.920 & 8.0 \\
\hline 7. & Monsanto India Ltd. & 1 & 0.00 & 1 & 0.00 & 1 & 0.00 \\
\hline 8. & Novartis India Ltd. & 1 & 0.00 & 1 & 0.00 & 1 & 0.00 \\
\hline 9. & Ondeo Nalco India Ltd. & 0.586 & 41.4 & 0.973 & 2.7 & 0.602 & 39.8 \\
\hline 10. & Pfizer India Ltd. & 0.684 & 31.6 & 0.761 & 23.9 & 0.899 & 10.1 \\
\hline 11. & Pharma Healthcare Ltd. & 0.739 & 26.1 & 0.760 & 24.0 & 0.972 & 2.8 \\
\hline 12. & Vanvil Dyes and Chemical Ltd. & 1 & 0.00 & 1 & 0.00 & 1 & 0.00 \\
\hline \multicolumn{8}{|c|}{ Panel C: Public Sector Firms } \\
\hline 1. & Fertilizer Chemicals, Travancore Ltd. & 0.435 & 56.5 & 0.456 & 54.4 & 0.954 & 4.6 \\
\hline 2. & Fertilizer Corporation of India Ltd. & 0.537 & 46.3 & 0.631 & 36.9 & 0.851 & 14.9 \\
\hline 3. & Hindustan Fertilizer Corpn Ltd. & 0.417 & 58.3 & 0.749 & 25.1 & 0.557 & 44.3 \\
\hline 4. & Hindustan Flurocarbons Ltd. & 0.220 & 78.0 & 0.440 & 56.0 & 0.500 & 50.0 \\
\hline 5. & Hindustan Insecticides Ltd. & 0.429 & 57.1 & 0.436 & 56.4 & 0.984 & 1.6 \\
\hline 6. & Hindustan Organic Chemical Ltd. & 0.581 & 41.9 & 0.625 & 37.5 & 0.930 & 7.0 \\
\hline 7. & Hindustan Salts Ltd. & 0.704 & 29.6 & 1 & 0.00 & 0.704 & 29.6 \\
\hline 8. & Madras Fertilizer Ltd. & 0.563 & 43.7 & 0.858 & 14.2 & 0.656 & 34.4 \\
\hline 9. & National Fertilizer Ltd. & 0.592 & 40.8 & 0.644 & 35.6 & 0.919 & 8.1 \\
\hline 10. & Rashtriya Chemicals and Fertilizer Ltd. & 0.921 & 7.90 & 1 & 0.00 & 0.921 & 7.9 \\
\hline 11. & Sambhar Salts Ltd. & 1 & 0.00 & 1 & 0.00 & 1 & 0.00 \\
\hline 12. & Southern Pesticides Corpn Ltd. & 0.460 & 54.0 & 0.550 & 45.0 & 0.836 & 16.4 \\
\hline \multicolumn{8}{|c|}{ Averages } \\
\hline \multicolumn{2}{|c|}{ Whole Sample } & 0.713 & 28.7 & 0.797 & 20.3 & 0.889 & 11.1 \\
\hline \multicolumn{2}{|c|}{ Private Domestic Firms } & 0.786 & 21.4 & 0.849 & 15.1 & 0.924 & 7.6 \\
\hline \multicolumn{2}{|c|}{ Private Foreign Firms } & 0.783 & 21.7 & 0.844 & 15.6 & 0.926 & 7.4 \\
\hline \multicolumn{2}{|c|}{ Public Sector Firms } & 0.572 & 42.8 & 0.699 & 30.1 & 0.818 & 18.2 \\
\hline \multicolumn{8}{|c|}{ Source: Authors' calculations } \\
\hline
\end{tabular}

Table 1: OTE, PTE and SE Scores for Private Domestic Firms, Private Foreign Firms and Public Sector Firms in the year 1990

from the table that of the 12 firms in the group, four are found to be technically efficient (as they have a score equal to one). These firms jointly define the best practice or efficiency frontier and thus form the reference set for inefficient firms. The input utilization process in these firms is functioning well and the production process is not characterized by any wastage of inputs. In DEA terminology, these firms are called 'peers' and set an example of good operating practices for inefficient firms to emulate. The presence of technically inefficient firms thus indicates the presence of marked deviations among firms from the best practice frontier. These inefficient firms can improve their efficiency by reducing inputs. On the whole, it can be observed that OTIE levels ranged from 4 percent to 61.7 percent among inefficient firms in the year 1990. 


\section{Decomposition of OTE: PTE and SE}

It is to be noted that the OTE measure helps to measure combined inefficiency that is due to both pure technical inefficiency (PTIE) and inefficiency that is due to inappropriate firm size, i.e. scale inefficiency (SIE). However, in contrast to the OTE measure, the PTE measure derived from the BCC model under the assumption of VRS voids the scale effects. Thus, the PTE scores provide that all the inefficiencies directly result from managerial underperformance (i.e. managerial inefficiency) in organizing the firm's inputs. It is again significant to note here that the efficiency scores of the firms rise upon allowing VRS because the BCC model (i.e. a DEA model under VRS assumption) forms a convex hull of intersecting planes which envelops the data point more tightly than the CRS conical hull and provides efficiency scores which are greater than or equal to those obtained using the CCR model (i.e. a DEA model under CRS assumption). In DEA literature, the firms attaining OTE and PTE scores equal to one are known as 'globally efficient' and 'locally efficient' firms respectively. Table I also provides the PTE and SE scores going after the abovementioned criteria. It can be observed that in the year 1990, of the 12 private sector domestic firms, four firms acquired the status of 'globally efficient firms' (OTE score $=1$ ) and 6 firms acquired the status of 'locally efficient firms' (PTE score $=1$ ). Ranbaxy Laboratories Ltd. and Addison Paints and Chemicals Ltd., whose PTE score $=1$ and OTE score $<1$, indicate that OTIE in these firms is not caused by poor input utilization (i.e. managerial inefficiency) but rather by the operations of the firms with inappropriate scale size. In the remaining six firms (with PTE $<1)$ managerial inefficiency exists, but of a different magnitude. In these firms, OTIE stems from both PTIE and SIE as indicated by the fact that these firms have both PTE and SE scores less than one. Out of these 6 firms, five firms have PTE scores less than SE scores. This indicates that the inefficiency in resource utilization (i.e. OTIE) in these five firms is mainly attributed to the managerial inefficiency rather than scale inefficiency.

Overall, from the whole group i.e. group I (consisting of private domestic firms) and its PTE and SE measures it can be observed from table I that the OTIE in this group is due to both poor input utilization (i.e. pure technical inefficiency) and failure to operate at the most productive scale size (i.e. scale inefficiency). The average PTE score for these twelve firms is 0.849 . This implies that 15.1 percentage points of the 21.4 percent of OTIE is due to poor management practices and selecting incorrect input combinations.

Now while taking the second group of firms, i.e. private firms with foreign ownership, it can be observed from the same table that the OTE (in percentage terms) of the private foreign firms is again characterized by asymmetry, as it ranges from 53.5 percent to 100 percent. The average efficiency score of these MNC's turned out to be 0.783 , which is marginally less than the private domestic firms (0.786). This means that the magnitude of the OTIE of private foreign firms in the Indian pharmaceutical industry is 21.7 percent. This finding further suggests that by adopting the best practice technology, these firms again can reduce their inputs of raw material, wages and salaries and gross fixed assets by at least 21.7 percent and still produce the same level of outputs. However, the scope of reduction of inputs varies from firm to firm in this group. In other words, these firms jointly have the scope of producing 1.28 times (i.e. $1 / 0.783$ ) as much output from the same level of inputs.

Of the total 12 firms in this group only 4 turned out to be technically efficient firms $(\mathrm{OTE}=1)$. However, compared to domestic firms overall inefficiency levels are low, as they ranged from 14.1 percent to 46.5 percent compared to the range of 4 percent to 61.7 percent in the case of private domestic firms in the same year i.e. 1990. While looking at the PTE and SE scores of these firms, it can be observed that exactly the same number of firms and same firms (i.e. four firms) acquired the status of 'globally efficient' firms and 'locally efficient' firms. This means that these four firms - Fulford India Ltd., Monsanto India Ltd., Novartis India Ltd. and Yanvil Dyes and Chemicals Ltd. are technically and managerially efficient. In the case of all the remaining 8 firms, PTE scores are less than SE scores. This means managerial inefficiency rather than scale inefficiency is dominant in these firms. The average PTE scored for these firms is 0.844 . This means that 15.6 percent of the 21.7 percent of OTIE is due to poor management practices and the selection of incorrect input combinations.

Now coming to the third group, i.e. public sector pharmaceutical firms in India, it can be observed from table I that out of 12 firms in this category, only one turned out to be 'globally efficient' and 3 can be designated 'locally efficient' firms. Overall OTIE scores ranged between 7.90 percent and 78.0 percent. Of the total 12 firms, in the case of 7 firms PTE scores are less than SE scores. This means that in the majority of the cases managerial inefficiency is greater than scale 


\begin{tabular}{|c|c|c|c|c|c|c|c|}
\hline \multicolumn{8}{|c|}{ Panel A: Private Domestic Firms } \\
\hline No. & Name of the firm & $\begin{array}{c}\text { OTE } \\
\text { Score }\end{array}$ & $\begin{array}{l}\text { OTIE } \\
(\%)\end{array}$ & $\begin{array}{c}\text { PTE } \\
\text { Score }\end{array}$ & $\begin{array}{l}\text { PTIE } \\
\text { (\%) }\end{array}$ & $\begin{array}{c}\text { SE } \\
\text { Score } \\
\end{array}$ & $\begin{array}{l}\text { SIE } \\
(\%)\end{array}$ \\
\hline 1. & Ambalal Sarabhai Enterprises Ltd. & 0.427 & 57.3 & 0.429 & 57.1 & 0.995 & 0.5 \\
\hline 2. & Amrutanjan Ltd. & 0.549 & 45.1 & 0.617 & 38.3 & 0.890 & 11.0 \\
\hline 3. & Cipla Ltd. & 0.776 & 22.4 & 1 & 0.00 & 0.776 & 22.4 \\
\hline 4. & Deepak Fertilizer and Petrochemicals Corpn. Ltd. & 0.790 & 21.0 & 0.857 & 14.3 & 0.922 & 7.8 \\
\hline 5. & Excel Industries Ltd. & 0.438 & 56.2 & 0.519 & 48.1 & 0.844 & 15.6 \\
\hline 6. & Kopran Ltd. & 0.52 & 48.0 & 0.541 & 45.9 & 0.961 & 3.9 \\
\hline 7. & Nagarjuna Fertilizers and Chemicals Ltd. & 1 & 0.00 & 1 & 0.00 & 1 & 0.00 \\
\hline 8. & Ranbaxy Laboratories Ltd. & 0.621 & 37.9 & 1 & 0.00 & 0.621 & 37.9 \\
\hline 9. & Southern Petrochemicals Inds. Corpn. Ltd. & 0.815 & 18.5 & 1 & 0.00 & 0.815 & 18.5 \\
\hline 10. & Sudarshan Chemicals Industries Ltd. & 0.500 & 50.0 & 0.515 & 48.5 & 0.971 & 2.9 \\
\hline 11. & Addisons Paints and Chemicals Ltd. & 0.625 & 37.5 & 0.915 & 8.50 & 0.638 & 36.2 \\
\hline 12. & Bihar Caustic and Chemical Ltd. & 0.720 & 28.0 & 0.820 & 18.0 & 0.878 & 12.2 \\
\hline \multicolumn{8}{|c|}{ Panel B: Private Foreign Firms } \\
\hline 1. & Abbott India Ltd. & 1 & 0.00 & 1 & 0.00 & 1 & 0.00 \\
\hline 2. & Albright and Wilson Chemicals India Ltd. & 0.442 & 55.8 & 0.511 & 48.9 & 0.865 & 13.5 \\
\hline 3. & Astrazencea Pharma India Ltd. & 0.478 & 52.2 & 0.485 & 51.5 & 0.986 & 1.4 \\
\hline 4. & Colour-Chem Ltd. & 0.457 & 54.3 & 0.465 & 53.5 & 0.983 & 1.7 \\
\hline 5. & Fulford (India) Ltd. & 1 & 0.00 & 1 & 0.00 & 1 & 0.00 \\
\hline 6. & Merck Ltd. & 0.573 & 42.7 & 0.589 & 41.1 & 0.973 & 2.7 \\
\hline 7. & Monsanto India Ltd. & 1 & 0.00 & 1 & 0.00 & 1 & 0.00 \\
\hline 8. & Novartis India Ltd. & 0.839 & 16.1 & 1 & 0.00 & 0.839 & 16.1 \\
\hline 9. & Ondeo Nalco India Ltd. & 0.584 & 41.6 & 0.733 & 26.7 & 0.797 & 30.3 \\
\hline 10. & Pfizer India Ltd. & 0.688 & 31.2 & 0.730 & 27.0 & 0.942 & 5.8 \\
\hline 11. & Pharma Healthcare Ltd. & 0.717 & 28.3 & 0.724 & 27.6 & 0.990 & 1.0 \\
\hline 12. & Vanvil Dyes and Chemical Ltd. & 0.692 & 30.8 & 0.828 & 17.2 & 0.836 & 16.4 \\
\hline \multicolumn{8}{|c|}{ Panel C: Public Sector Firms } \\
\hline 1. & Fertilizer Chemicals, Travancore Ltd. & 0.462 & 53.8 & 0.704 & 29.6 & 0.656 & 34.4 \\
\hline 2. & Fertilizer Corporation of India Ltd. & 0.212 & 78.8 & 0.214 & 78.6 & 0.991 & 0.9 \\
\hline 3. & Hindustan Fertilizer Corpn Ltd. & 0.276 & 72.4 & 0.746 & 25.4 & 0.370 & 63.0 \\
\hline 4. & Hindustan Flurocarbons Ltd. & 0.362 & 63.8 & 0.663 & 33.7 & 0.546 & 45.4 \\
\hline 5. & Hindustan Insecticides Ltd. & 0.303 & 69.7 & 0.305 & 69.5 & 0.993 & 0.7 \\
\hline 6. & Hindustan Organic Chemical Ltd. & 0.329 & 67.1 & 0.330 & 67.0 & 0.997 & 0.3 \\
\hline 7. & Hindustan Salts Ltd. & 1 & 0.00 & 1 & 0.00 & 1 & 0.0 \\
\hline 8. & Madras Fertilizer Ltd. & 0.463 & 53.7 & 0.862 & 13.8 & 0.537 & 46.3 \\
\hline 9. & National Fertilizer Ltd. & 0.525 & 47.5 & 0.951 & 4.9 & 0.552 & 44.8 \\
\hline 10. & Rashtriya Chemicals and Fertilizer Ltd. & 0.729 & 27.1 & 1 & 0.00 & 0.729 & 27.1 \\
\hline 11. & Sambhar Salts Ltd. & 1 & 0.00 & 1 & 0.00 & 1 & 0.00 \\
\hline 12. & Southern Pesticides Corpn Ltd. & 0.147 & 85.3 & 0.737 & 26.3 & 0.199 & 80.1 \\
\hline \multicolumn{8}{|c|}{ Averages } \\
\hline \multicolumn{2}{|c|}{ Whole Sample } & 0.613 & 38.7 & 0.744 & 25.6 & 0.837 & 16.3 \\
\hline \multicolumn{2}{|c|}{ Private Domestic Firms } & 0.648 & 35.2 & 0.768 & 23.2 & 0.863 & 13.7 \\
\hline \multicolumn{2}{|c|}{ Private Foreign Firms } & 0.706 & 29.4 & 0.755 & 24.5 & 0.934 & 6.6 \\
\hline \multicolumn{2}{|c|}{ Public Sector Firms } & 0.484 & 51.6 & 0.709 & 29.1 & 0.714 & 28.6 \\
\hline
\end{tabular}

Table 2: OTE, PTE and SE Scores for Private Domestic Firms, Private Foreign Firms and Public Sector Firms in the year 2000

inefficiency. The average PTE scores in this case are 0.699. This means that of the total 42.8 percent inefficiency, 30.1 percent are due to poor management skills in the year 1990. The average scale inefficiency score in the case of public sector firms turned out to be 0.818 in the year 1990.

Table 2 of the study depicts the overall technical efficiency, pure technical efficiency and scale efficiency scores of private domestic firms, private foreign firms and public sector firms of the Indian pharmaceutical industry for the year 2000 (representing the post reform period). A comparative analysis for the years 1990 to 2000 shows that average OTE scores have decreased in the case of all three groups in the post reform period. The scores from the year 2000 for private domestic firms, private foreign firms and public sector firms are $0.648,0.706$ and 0.484 , respectively, as compared to $0.786,0.783$ and 0.572 , respectively, in the year 1990. The highest decrease in efficiency is in the case of private domestic firms followed by public sector firms and private foreign firms. This 


\begin{tabular}{|c|c|c|c|c|c|c|c|}
\hline \multicolumn{8}{|c|}{ Panel A: Private Domestic Firms } \\
\hline No. & Name of the firm & $\begin{array}{c}\text { OTE } \\
\text { Score }\end{array}$ & $\begin{array}{c}\text { OTIE } \\
(\%)\end{array}$ & $\begin{array}{c}\text { PTE } \\
\text { Score }\end{array}$ & $\begin{array}{l}\text { PTIE } \\
(\%)\end{array}$ & $\begin{array}{c}\text { SE } \\
\text { Score } \\
\end{array}$ & $\begin{array}{l}\text { SIE } \\
\text { (\%) }\end{array}$ \\
\hline 1. & Ambalal Sarabhai Enterprises Ltd. & 0.717 & 28.3 & 0.202 & 79.8 & 0.847 & 15.3 \\
\hline 2. & Amrutanjan Ltd. & 0.352 & 64.8 & 0.504 & 49.6 & 0.698 & 30.2 \\
\hline 3. & Cipla Ltd. & 0.945 & 5.5 & 1 & 0.00 & 0.945 & 5.5 \\
\hline 4. & Deepak Fertilizer and Petrochemicals Corpn. Ltd. & 0.575 & 42.5 & 0.575 & 42.5 & 1 & 0.00 \\
\hline 5. & Excel Industries Ltd. & 0.402 & 59.8 & 0.437 & 56.3 & 0.920 & 8.0 \\
\hline 6. & Kopran Ltd. & 0.480 & 52.0 & 0.564 & 43.6 & 0.851 & 14.9 \\
\hline 7. & Nagarjuna Fertilizers and Chemicals Ltd. & 1 & 0.00 & 1 & 0.00 & 1 & 0.00 \\
\hline 8. & Ranbaxy Laboratories Ltd. & 0.839 & 16.1 & 1 & 0.00 & 0.839 & 16.1 \\
\hline 9. & Southern Petrochemicals Inds. Corpn. Ltd. & 0.653 & 34.7 & 0.681 & 31.9 & 0.959 & 4.1 \\
\hline 10. & Sudarshan Chemicals Industries Ltd. & 0.599 & 40.1 & 0.610 & 39.0 & 0.982 & 1.8 \\
\hline 11. & Addisons Paints and Chemicals Ltd. & 0.360 & 64.0 & 1 & 0.00 & 0.360 & 64.0 \\
\hline 12. & Bihar Caustic and Chemical Ltd. & 0.519 & 48.1 & 0.662 & 33.8 & 0.784 & 21.6 \\
\hline \multicolumn{8}{|c|}{ Panel B: Private Foreign Firms } \\
\hline 1. & Abbott India Ltd. & 1 & 0.00 & 1 & 0.00 & 1 & 0.00 \\
\hline 2. & Albright and Wilson Chemicals India Ltd. & 0.741 & 25.9 & 0.912 & 8.8 & 0.813 & 18.7 \\
\hline 3. & Astrazencea Pharma India Ltd. & 0.379 & 62.1 & 0.398 & 60.2 & 0.952 & 4.8 \\
\hline 4. & Colour-Chem Ltd. & 0.432 & 56.8 & 0.433 & 56.7 & 0.998 & 0.20 \\
\hline 5. & Fulford (India) Ltd. & 1 & 0.00 & 1 & 0.00 & 1 & 0.00 \\
\hline 6. & Merck Ltd. & 0.599 & 40.1 & 0.602 & 39.8 & 0.995 & 0.50 \\
\hline 7. & Monsanto India Ltd. & 1 & 0.00 & 1 & 0.00 & 1 & 0.00 \\
\hline 8. & Novartis India Ltd. & 1 & 0.00 & 1 & 0.00 & 1 & 0.00 \\
\hline 9. & Ondeo Nalco India Ltd. & 0.558 & 44.2 & 0.717 & 28.3 & 0.778 & 22.2 \\
\hline 10. & Pfizer India Ltd. & 0.499 & 50.1 & 0.702 & 29.8 & 0.711 & 28.9 \\
\hline 11. & Pharma Healthcare Ltd. & 0.236 & 76.4 & 0.445 & 55.5 & 0.530 & 47.0 \\
\hline 12. & Vanvil Dyes and Chemical Ltd. & 0.451 & 54.9 & 0.693 & 30.7 & 0.651 & 34.9 \\
\hline \multicolumn{8}{|c|}{ Panel C: Public Sector Firms } \\
\hline 1. & Fertilizer Chemicals, Travancore Ltd. & 0.323 & 67.7 & 0.398 & 60.2 & 0.812 & 18.8 \\
\hline 2. & Fertilizer Corporation of India Ltd. & 0.068 & 93.2 & 1 & 0.00 & 0.068 & 93.2 \\
\hline 3. & Hindustan Fertilizer Corpn Ltd. & 0.213 & 78.7 & 0.259 & 74.1 & 0.822 & 17.8 \\
\hline 4. & Hindustan Flurocarbons Ltd. & 0.25 & 75.0 & 0.614 & 38.6 & 0.407 & 59.3 \\
\hline 5. & Hindustan Insecticides Ltd. & 0.194 & 80.6 & 0.213 & 78.7 & 0.911 & 8.9 \\
\hline 6. & Hindustan Organic Chemical Ltd. & 0.392 & 60.8 & 0.393 & 60.7 & 0.997 & 0.3 \\
\hline 7. & Hindustan Salts Ltd. & 0.377 & 62.3 & 1 & 0.00 & 0.377 & 62.3 \\
\hline 8. & Madras Fertilizer Ltd. & 1 & 0.00 & 1 & 0.00 & 1 & 0.00 \\
\hline 9. & National Fertilizer Ltd. & 0.876 & 12.4 & 1 & 0.00 & 0.876 & 12.4 \\
\hline 10. & Rashtriya Chemicals and Fertilizer Ltd. & 0.839 & 16.1 & 1 & 0.00 & 0.839 & 16.1 \\
\hline 11. & Sambhar Salts Ltd. & 1 & 0.00 & 1 & 0.00 & 1 & 0.00 \\
\hline 12. & Southern Pesticides Corpn Ltd. & 0.028 & 97.2 & 1 & 0.00 & 0.028 & 97.2 \\
\hline \multicolumn{8}{|c|}{ Averages } \\
\hline \multicolumn{2}{|c|}{ Whole Sample } & 0.565 & 43.5 & 0.723 & 27.7 & 0.799 & 20.1 \\
\hline \multicolumn{2}{|c|}{ Private Domestic Firms } & 0.575 & 42.5 & 0.686 & 31.4 & 0.849 & 15.1 \\
\hline \multicolumn{2}{|c|}{ Private Foreign Firms } & 0.658 & 34.2 & 0.742 & 25.8 & 0.869 & 23.1 \\
\hline \multicolumn{2}{|c|}{ Public Sector Firms } & 0.463 & 53.7 & 0.740 & 26.0 & 0.678 & 32.2 \\
\hline
\end{tabular}

Table 3: OTE, PTE and SE Scores for Private Domestic Firms, Private Foreign Firms and Public Sector Firms in the year 2004

implies that the magnitude of OTIE in the case of private domestic firms, foreign private firms and public sector firms is 35.2 percent, 29.4 percent and 51.6 percent, respectively. The overall OTIE (of all the 36 firms) is 38.7 percent in the year 2000, which was 28.7 in the year 1990 .

Of the 12 private domestic firms only one firm can be seen as optimally efficient (with OTE $=1$ ), whereas OTE is
3 in the case of private foreign firms and 2 in the case of public sector firms. Only one firm in the case of private domestic firms acquired the status of 'globally efficient firm' while 4 firms got the 'locally efficient firm' status in the year 2000. The figure for private foreign firms in the same year is 3 and 4, respectively, whereas it is 2 and 3 , respectively for public sector firms. In the case of the 
three private domestic firms - Cipla Ltd., Ranbaxy Laboratories Ltd. and Southern Petrochemicals Ind. Corp. Ltd., the PTE score is $=1$ and OTE score is $<1$. This shows that the OTIE of these firms is not due to managerial inefficiency but to inappropriate scale size. In the case of private foreign firms, this type of inefficiency exists only in case of one firm, i.e. Novartis India Ltd. The same situation is the case among public sector firms, where only in one case is the OTE score less than the PTE score.

Out of the 12 private domestic firms the PTE score in the case of 7 firms is less than the SE score. This means that managerial inefficiency is greater than scale inefficiency. The number of such firms is 8 in the case of private foreign firms and only 3 in the case of public sector firms. This indicates that managerial efficiency in public sector units in the year 2000 has improved and is the best among both private domestic and private foreign firms. Overall, in all three groups the existence of managerial inefficiency is dominant over scale inefficiency.

Table 3 exhibits the overall technical efficiency, pure technical efficiency and scale efficiency of the private domestic firms, private foreign firms (MNC's) and public sector firms of the pharmaceutical industry of India in the year 2004, representing the post-reform period. The visibly clear observation that emerges from the average efficiency scores is that in all the three groups the average OTE, PTE and SE scores have decreased further even compared to the years 2000 and 1990. The highest average overall technical efficiency scores of these firms were in the pre-reform period, i.e. in 1990, followed by the year 2000 while the least are in the year 2004. The average OTE scores of private domestic firms, private foreign firms and public sector firms are $0.575,0.658$ and 0.463 , respectively. The PTE scores for these firms are $0.686,0.742$ and 0.740 , respectively, whereas the SE scores are $0.849,0.869$ and 0.678 , respectively, in the year 2004. The overall OTIE is 43.5 percent, which was 28.7 percent in the year 2000 and 38.7 percent in the year 1990. The average PTIE turned out to be 27.7 percent in the year 2004, 20.3 percent in the year 2000 and 25.6 percent in the year 1990. This implies that pure technical inefficiency decreased after the introduction of reforms, i.e. in 2000, but again increased in the year 2004. The same happened in the case of average scale inefficiency which was 16.3 percent in the year 1990, decreased to 11.1 percent in the year 2000 but again increased to 20.1 percent in the year 2004.
Only one firm of the 12 private domestic firms acquired the status of a 'globally efficient' firm in 2004, whereas there are 4 'locally efficient' firms. In the case of private foreign firms, there were 3 'globally efficient' firms and 4 'locally efficient' firms. The number of 'locally efficient' firms reached 7 the in case of public sector firms and there were 2 'globally efficient' firms. Six public sector firms had a scale efficiency scores < PTE score. This implies that scale inefficiency is dominant in the case of public sector firms in the year 2004 rather than managerial inefficiency. On the other hand, in the case of 6 private foreign firms the PTE score is < SE score, indicating that managerial inefficiency in these firms is greater than the scale inefficiency. In the case of private domestic firms again managerial inefficiency was dominant over scale inefficiency in the year 2004.

Overall, again it can be observed that the OTIE is both due to poor input utilization and failure to operate at optimum scale size. All the 36 firms taken together have a scope of producing 1.79 times as much output from the same level of inputs by improving managerial and scale efficiencies. Individually, the private domestic firms have a scope of increasing output by 1.74 times while employing the same level of inputs in the year 2004. Private foreign firms have a scope of increasing output by 1.52 times and public sector firms can more than double output (i.e. 2.16 times) while utilizing the same level of inputs.

As mentioned earlier, a Mann Whitney test was applied to check whether the difference of efficiency scores among different sets of firms is significant or not. Table IV of the study shows that overall technical efficiency (OTE) is significantly different in the case of private domestic firms and public sector firms, in the case of private foreign firms and public sector firms and all private and public sector firms in the year 1990. However, in the same year, overall technical efficiency was not significantly different in the case of domestic private firms and foreign private firms. As for the pure technical efficiency scores between different groups of firms, in the year 1990 there was no statistically significant difference. Scale efficiency differs significantly between domestic private firms and public sector firms.

Table 4 of the study also shows that overall technical efficiency is significantly different only in the case of private foreign firms and public sector firms and private domestic firms and public sector firms in the year 2000 . There was no significant difference between scale efficiency and pure technical efficiency of the firms with 


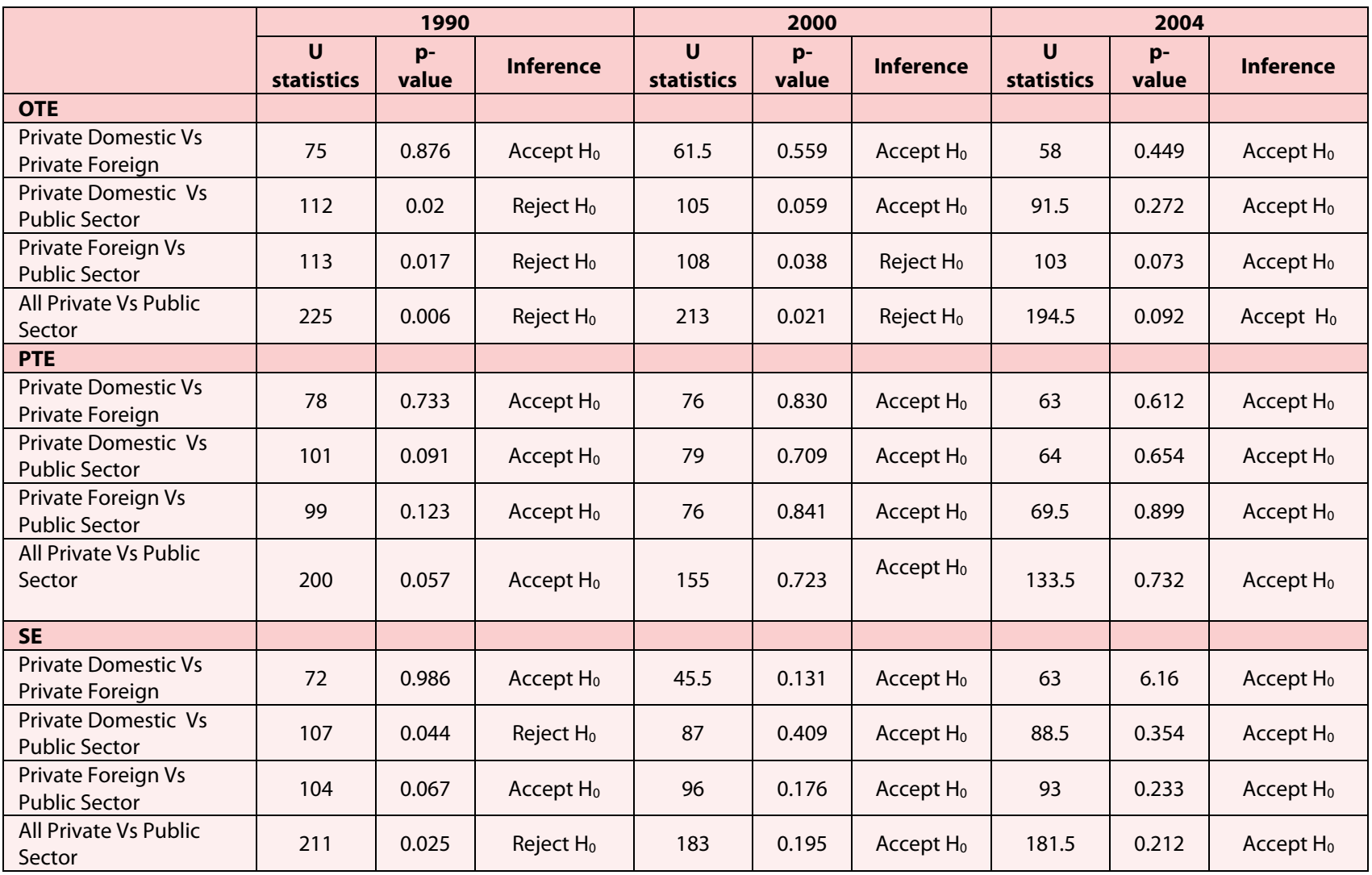

Source: Authors' calculations

Table 4: Hypothesis Testing using Mann-Whitney test

different ownership patterns in the year 2000. From table 4 it can further be observed that ownership pattern failed to cause any significant difference in OTE, PTE and SE in the 2004. The 2004 levels of efficiency of private domestic, private foreign and public sector firms were different, but these differences were not found to be statistically significant.

\section{Summary and Conclusions}

The study tries to evaluate the extent of technical, pure technical and scale efficiencies of the firms categorized on the basis of ownership pattern as private domestic firms, private foreign firms and public sector firms of the Indian pharmaceutical industry. To realize the objectives of the study, a DEA frame work has been applied in which the estimates of technical, pure technical and scale efficiencies for individual firms have been obtained by CCR and BCC models at three points of time i.e. 1990 (indicating the pre-reform period) and 2000 and 2004 (indicating the post-reform period). Three input measures (raw material cost, wages and salaries and fixed assets) and one output measure (net sales) were used.
The results indicate that the OTE (in percentage terms) of private domestic firms ranges between 38.3 percent and 100 percent for the year 1990 . The magnitude of overall technical inefficiency is 21.4 percent in this case. This suggests that by adopting best practice technology, these firms can reduce their inputs of raw material, wages and salaries and gross fixed assets by at least 21.4 percent and still produce the same level of output. Alternatively these firms have the scope of producing 1.27 times as much as output from the same level of inputs. The magnitude of OTIE of the private foreign firms of the Indian pharmaceutical industry is 21.7 percent for 1990, which is marginally higher than that of private domestic firms.

A comparative analysis for the years 1990 and 2000 shows that average overall technical efficiency scores have decreased in the case of all three groups in the postreform years. The highest decrease in efficiency is in the case of private domestic firms followed by public sector firms and private foreign firms. The results also indicate that managerial efficiency in the public sector units in the year 2000 improved and turned out to be the best among private domestic and private foreign firms. However, in 
the year 2004, the visibly clear observation from the efficiency scores was that in all three groups of firms the average OTE, PTE and SE scores decreased further compared to 1990 and 2000. The highest average overall technical efficiency scores of these firms were in the year 1990, followed by 2000, while the least were in 2004. Overall, from the whole analysis it can be observed that overall technical inefficiency is both due to poor input utilization (i.e. managerial inefficiency) and the failure to operate at the most productive scale size (i.e. scale inefficiency), although managerial inefficiency dominated all three years among these groups of firms. This means that the firms are more successful in choosing optimal levels of output than adopting best practice technology.

The application of a non-parametric Mann-Whitney Test shows that overall technical efficiency was different in the case of private domestic and public sector firms in the year 1990. The difference was also significant in the case of private foreign and public sector firms, though it was not significant in the case of private domestic and private foreign firms in the pre-reform period. This means that there is a significant role for management and ownership in the overall technical efficiency of these firms. Private sector firms seemed more efficient than public sector firms. This was true in the case of scale efficiency, where again significant differences in scale efficiency emerged between public and private sector firms in 1990. Overall technical efficiency scores were also significantly different in the case of public sector and private sector (both foreign and domestic) firms in the year 2000 (i.e. in the post-reform period). In the subsequent years and in the case of scale efficiency and pure technical efficiency, there were no significant differences for the firms in terms of different ownership patterns.

On the basis of the above findings the study rejects the argument that foreign firms are more efficient than domestic firms and that private firms are more efficient than public sector firms. The significant difference in OTE in the pre-reform year (i.e. 1990) indicates that there might be significant differences in the technology being used by domestic and foreign firms. However, after the reforms (i.e. in the years 2000 and 2004) the nonsignificant difference in OTE in the case of domestic, foreign and public sector firms may imply that there might be speedy technological spillovers among the firms in India. It can therefore be argued that the Indian firms are catching up with foreign firms quite well after the liberalization process. The dominance of management inefficiency in case of all the three categories of firms indicates that even foreign technology brought by the foreign firms has not induced any competition and the presence of foreign firms has not increased efficiency in domestic firms. This may also be due to poor absorption or diffusion of foreign technology. The efficiency of the foreign firms is on par with the domestic firms, implying that even if foreign firms have brought better technology, domestic business environment and human capital might not be matching factors to generate spillovers. The study suggests that there is ample scope for increasing the efficiency of firms in the Indian pharmaceutical industry by choosing the correct input-output mix and selecting appropriate scale size. The spillover effects can be boosted by creating a better business environment and developing human capital, so that there is no mismatch between domestic human capital and foreign technology. $匚$.

\section{References}

Aitken, B. J., Harrison, A. E. 1999. Do Domestic Firms Benefit from Direct Foreign Investment? Evidence from Venezuela, American Economic Review 89(3): 605-618.

Alfero L., A. Chanda, S. Kalemli-Ozcan and S. Sayek, 2003. FDI and Economic Growth: The Role of Local Financial Markets. Journal of International Economics 64: 89-112.

Barbose, N. and Louri, H. 2005. Corporate Performance, Does Ownership Matter? A Comparison of Foreign and Domestic-Owned Firms in Greece and Portugal. Review of Industrial Organization 27: 73102.

Bernard, A. B. and Bradford, J. J. 2004. Exporting and Productivity in the US. Oxford Review of Economic Policy 20(3): 343-357.

Barros, C. P. and Mascarenhas, M. J. 2005. Technical and Allocative Efficiency in a Chain of Small Hotels. Hospitality Management 24(3): 41536.

Blomstrom, M. 1990. Foreign Investment and Spillovers. Routledge. London.

Blomstrom, M., R. E. Lipsey, and M. Zejan. 1992. What Explains Developing Country Growth. NBER Working Paper Series No. 4132.

Borensztein, E. De Gregorio, J. and Lee, J-W. 1998. How Does Foreign Direct Investment Affect Economic Growth? Journal of International Economics. Elseveer, 45(1): 115-135.

Charnes, A., Cooper, W. W., Lewin, A. Y. and Secford, L. M. Ed. 1994. Data Envelopment Analysis: Theory, Methodology and Applications: Dordrecht Kluwer Academic Publishers.

Chhibber, P. K. and Majumdar, S. K. 1997. Foreign Ownership and Profitability: Property Rights, Strategic Control and Corporate Performance in Indian Industry. William Davidson Institute Working Papers Series 64, William Davidson Institute at the University of Michigan Stephen M. Ross Business School.

Durham, J. B. 2003. Foreign Portfolio Investment, Foreign Banks Lending and Economic Growth. International Finance Discussion Papers 757, Board of Governors of the Federal Reserve System (U.S). 
Durham, J. B. 2004. Absorptive Capacity and the Effects of Foreign Direct Investment and Equity Foreign Portfolio Investment on Economic Growth, European Economic Review 48: 285-306.

Farrell, M. J. 1957. The Measurement of Productive Efficiency. Journal of the Royal Statistical Society Serves. A. 120(3): 253-290.

Goldar, B. N., Ranganathan, V. S. and Banga, R. 2003. Ownership and Efficiency in Engineering Firms in India, 1990-91 to 1999-2000 Working Paper No. 115, Indian Council for Research on International Economic Relations: New Delhi.

Hallward-Driemeier, M. larossi, G. and Sokoloff, K. L. 2002. Exports and Manufacturing Productivity in East Asia: A Comparative Analysis with Firm-Level Data. NBER Working Paper 8894. National Bureau of Economic Research.

Helpman, E., M. J. Melitz and S. R. Yeaple. 2004. Export Versus FDI with Heterogeneous Firms. The American Economic Review 94(1): 300-317.

Hill, H. 1988. Foreign Investment and Industrialization in Indonesia. Oxford University Press, Singapore.

Kathuria, V. 2000. Liberalization, FDI and Productivity Spillover: An Analysis of Indian Manufacturing Firms. Oxford Economic Papers 54: 688-718.

Konings, J. and Murphey, A. 2001. Do Multinational Enterprises Substitute Parent Jobs for Foreign Ones? Evidence from Firm Level Panel Data. William Davidson Institute Working Papers Series 371. William Davidson Institute at the University of Michigan, Stephen M. Ross Business School.
Oguchi, N. 2002. Productivity of Foreign and Domestic Firms in Malaysian Manufacturing Industry. Asian Economic Journal. 16(3): 215228.

Pandit, B. L. and Siddharthan, N. S. 2003. MNEs and Market Valuation of Firms: a Cross-Sectional Study of Indian Electrical and Electric Goods Manufacturing Firms. Applied Economics 35(6): 675-681.

Ramstetter, E. D. 1999. Comparisons of Foreign Multinational and Local Firms in Asian Manufacturing Over Time. Asian Economic Journal. 13(3): 163-203.

Sjoholm, F. 1998. Joint Ventures, Technology Transfer and Spillovers: Evidence from Indonesian Establishment Data. In Economic Planning Agency, ed. Foreign Direct Investment in Asia, Papers and Proceedings of an International Symposium, October 22-23, Economic Planning Agency, Tokyo. 587-616.

Takii, S. and Ramstetter, E. D. 2000. Foreign Multinationals in Indonesian Manufacturing 1985-1998: Shares, Relative Size and Relative Labour Productivity Working Paper 2000-18. International Centre for the Study of East Asian Development. Kitakyushu.

Takii, S. 2002. Productivity Differentials between Local and Foreign Plants in Indonesian Manufacturing, 1995. Working Paper 2002, International Centre for the Study of East Asian Development. Kitakyushu.

\section{Appendix A:Mann-Whiney U test}

The Mann-Whiney $U$ test is one of the most powerful non-parametric tests for comparing two independent groups of sampled data. Unlike the parametric $t$-test, it makes no assumptions about the distribution of the data. It uses the ranks of the data rather than their raw values to calculate the test statistic. The result of the Mann-Whiney $U$ test indicates if there is a significant difference between the median of the two samples. To proceed with the test, the two samples are combined together and ranked from the smallest to the largest value. If the test statistic, which might be the sum of the ranks assigned to one sample, is too small (or too large), then it can be concluded that the values from that population tend to be smaller (or larger) than the other population. It is used for testing the null hypothesis that the two samples have been drawn from the same population. The test hypotheses can be shown as follows:

$H_{0}$ : Population distribution functions of the samples are identical.

$H_{1}$ : The two populations do not have the same means.

The implementation procedure of Mann-Whiney $U$ test can be outlined as follows:

1. Consider two groups with $m$ and $n$ observations, respectively. All the observations from the two groups are sorted (ascending order) and ranked (the smallest value gets a rank of 1). In the case of tied observation values, the average of the ranks of the underlying observations is assigned to each.

2. Let $R_{1}$ be the sum of the ranks of the first group and $R_{2}$ be the sum of the ranks of the second group. The test statistic $U$ is the smaller of the two quantities $U_{1}$ and $U_{2}$ and is calculated as follows:

$$
\begin{aligned}
& U_{1}=m n+\frac{m(m+1)}{2} R_{1} \\
& U_{2}=m n+\frac{n(n+1)}{2} R_{2} \\
& U=\min \left(U_{1}, U_{2}\right) .
\end{aligned}
$$

1. The null hypothesis is rejected at a confidence level of $\alpha$ if the computed value of $U$ is less than or equal to the critical value of $U(m, n, \alpha)$. For smaller sample sizes $(m<20, n<20)$, this critical value can be found in tables available in statistical books and for larger sample sizes it can be approximated using

$$
U(m, n, \alpha)=\frac{m n}{2}-Z\left[\sqrt{\frac{m n(m+n+1)}{12}}\right]
$$

In the above equation, $Z$ is the $Z$-value of the standard normal distribution at $\alpha$ level. 